\title{
Research Paper \\ The Effect of Hydroethanolic Extract of Pomegranate Peels and High-intense Inter- val Training on C-reactive Protein, Catalase and Superoxide Dismutase in Rats
}

\author{
${ }^{*}$ Farah Nameni ${ }^{1}$ (D), Roya Aliakbar Alavi ${ }^{1}$
}

1. Department of Sports Physiology, Varamin Pishva Branch, Islamic Azad University, Varamin, Iran

\begin{tabular}{|c|c|}
\hline $\begin{array}{l}\text { Use your device to scan } \\
\text { and read the article online }\end{array}$ & \\
\hline 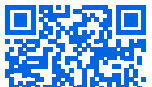 & $\begin{array}{l}\text { Training on C-reactive Protein, Catalase and Superoxide Dismutase in Rats (Persian)]. Quarterly of "The Horizon of Medical Sci- } \\
\text { ences". 2021; 27(2):182-197. https://doi.org/10.32598/hms.27.2.1303.2 }\end{array}$ \\
\hline ateris & doi https://doi.org/10.32598/hms.27.2.1303.2 \\
\hline
\end{tabular}

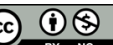

Received: 10 Jul 2020 Accepted: 16 Nov 2020 Available Online: 01 Apr 2021

Keywords: Interval training, Inflammation, Antioxidant enzyme, Pomegranate supplementation

\begin{abstract}
Aims Heavy exercise can damage the immune system by oxidative stress. The role of herbal supplements during and after strenuous exercise is unknown. Therefore, the present study aimed to determine hydroethanolic extract of pomegranate peels and a period of high-intensity interval training on the C-reactive protein and antioxidant enzyme activity in rats.

Methods \& Materials This research was an experimental study. The statistical population was rats, of which 36 Wistar rats were randomly selected and were divided into 4 groups (control, hydroethanolic extract of pomegranate peels, high-intensity interval training, and hydroethanolic extract of pomegranate peels + high-intensity interval training). After 8 weeks of interval training and supplementation, blood samples were taken from the rats. Then, the C-reactive protein and the activity of the antioxidant enzymes of superoxide dismutase and catalase were assessed by 1-way analysis of variance.

Findings The results showed that in the group of hydroethanolic extract of pomegranate peels + highintensity interval training, the superoxide dismutase $(P=0.000)$ and catalase $(P=0.003)$ significantly increased, and the $\mathrm{C}$-reactive protein ( $\mathrm{P}=0.002)$ decreased. Tukey's test confirmed the significance of these changes in the hydroethanolic extract of pomegranate peels+high-intensity interval training compared to the control group.

Conclusion The combination of high-intensity interval training and hydroethanolic extract of pomegranate peels could strengthen the immune system, potentially enhances athletic performance, and accelerates recovery after exercises. The hydroethanolic extract of pomegranate peels and high-interval training synergistically boost the immune system and increase physical endurance.
\end{abstract}

\section{English Version}

\section{Introduction}

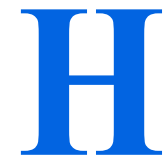

igh-Intensity exercise, with high oxygen consumption, causes excessive free radicals production inside the cell [1]. These radicals may affect the musculoskeletal and heart system elements, inflammatory fac- tors, and antioxidants [2]. The antioxidant defense is part of the body's immune system to fight free radicals and oxidative stress [3].

Evidence suggests that heavy physical activity increases the production of free radicals in skeletal muscle and active tissues. Therefore, the effect of interval exercise on cytokine levels and immune system indices is considered [3]. It is unclear how intense and when these sports activities can be

\section{Corresponding Author:}

Farah Nameni, PhD.

Address: Department of Sports Physiology, Varamin Pishva Branch, Islamic Azad University, Varamin, Iran.

Tel: +98 (912) 5354053

E-mail: f.nameni@yahoo.co.uk 
effective [4]. Studies show that a combination of physical activity and the use of dietary supplements containing antioxidants can control inflammatory cytokines [5].

Herbal medicine as a complementary treatment method can effectively improve the antioxidant conditions and cleansing the body of free radicals, and controlling inflammatory cytokines. In this regard, the pomegranate pill supplement has been considered because of its compounds such as alkaloids, flavonoids, organic acids, and various vitamins [6]. Because of its unique polyphenolic compounds, pomegranate protects against damage to macromolecules, including membrane proteins and DNA, and inflammatory and muscle damage by reducing the oxidative stress process in athletes. Besides, pomegranate pill supplement may increase exercise performance and reduce undesirable blood lipids [7].

Some other medical and clinical effects of bioactive compounds in pomegranate inhibit uncontrolled cell growth and planned death of cancer cells [8]. Pomegranate is also a source of secondary metabolic compounds (lignin, sterols, and terpenoids) [9] and can be referred to as the alkaloids in the skin and leaves and triglyceride fatty acids in pomegranate seed oil [9]. The compounds of coumarin, tannins, flavonoids, anthocyanins, ester derivatives, or glycosidic derivatives soluble in pomegranate juice have also added to the medicinal value of this supplement [10]. The effect of this supplement on antioxidant indices and inflammatory and blood factors pomegranate and immune responses in interval exercise can be a practical step to understand better the relationship between the immune system and supplement consumption in athletes.

Cytokines have anti-inflammatory and immune-regulating properties that limit inflammatory responses caused by tissue damage in athletes and, in addition to immune function, have metabolic function [10]. A major mediator of inflammatory reactions that increase in sports injuries is $\mathrm{C}$ Reactive Protein (CRP). This mediator can bind to nuclear antigens, specific pathogens, and damaged tissues [11].

The effect of pomegranate pill supplement on immune cytokines and biochemical markers of inflammation can provide helpful information about the anti-inflammatory effects of pomegranate in preventing oxidative damage in athletes. It also provides a good perspective on the design and use of antioxidant supplements and their protective effects during intermittent exercises. Also, the use of pomegranate pill supplements in improving the performance of different parts of the body and counteracting the effects of exercise and sports activity may have beneficial effects. This study aimed to evaluate the effect of hydroethanolic extract of pomegranate peels and a period of intense interval training on CRP, Catalase (CAT), and Superoxide Dismutase (SOD) in rats.

\section{Materials and Methods}

This research was carried out by experimental or interventional laboratory study, post-test design with a control group. It is an applied study in terms of purpose. Also, this study has an ethical code approved by the Faculty of Medical Sciences of the Islamic Azad University, Varamin Pishva Branch, Tehran, Iran. In all stages of maintenance, sports activities, and supplementation, the ethical principles of working with animals have been observed following the Helsinki Declaration regulations. The study's statistical population comprised male Wistar rats, and the sample consisted of 36 adult male Wistar rats weighing $260 \pm 32 \mathrm{~g}$ and 8 weeks old, prepared from the center of Pasteur Institute of Iran and transferred to the laboratory of Islamic Azad University, Varamin Branch. The rats were exposed to an appropriate temperature and living conditions.

In each cage, 4 mice were kept in a natural light cycle (12 hours of light and 12 hours of darkness). The rats were transferred to the laboratory to get familiar with the new environment and work on the treadmill. Two weeks later, they were randomly divided into four groups: control group (daily intake of $1 \mathrm{~mL}$ of freshwater by gavage), the second group (Daily intake of $1 \mathrm{~mL}$ of pomegranate peel hydroethanolic extract by gavage), group 3 (daily intake of $1 \mathrm{~mL}$ of pomegranate peel hydroethanolic extract by gavage and a period of intense intermittent exercise) and group 4 (intake of $1 \mathrm{~mL}$ of freshwater with gavage and a period of intense intermittent exercise).

The inclusion criteria included proper weight, age, sex, without previous drug use or supplement, and exclusion criteria included disease and physiological heterogeneity and lack of rats' similar race. The test period took 8 weeks. Because the rats' transfer caused stress in them, the rats were kept for one week after transfer to adapt to the environment. Then, to get acquainted with the treadmill, they performed increasing interval exercises with low intensity for one week. The introductory program with intense intermittent training included 4 training sessions per week, consisted of walking and running on an electronic treadmill for rodents (made by IranPishro AndisheSanat, Iran) (Table 1).

The rats had increased training in the first 5 weeks and then decreased training load in the last two weeks. The main activity time was 30 minutes and 5 minutes for warming up and 5 minutes for cooling down. To stimulate the rats to run, a gentle electric shock was installed in the back 
Table 1. Subjects' 8-week interval training program

\begin{tabular}{|c|c|c|c|c|c|c|c|c|c|}
\hline Week & Getting to Know & First & Second & Third & Fourth & Fifth & Sixth & Seventh & Eighth \\
\hline Exercise speed ${ }^{*}$ & $10-25$ & $25-35$ & $25-35$ & $25-35$ & $30-45$ & $45-55$ & $50-65$ & $60-70$ & $60-70$ \\
\hline Training duration & \multicolumn{9}{|c|}{1 minute } \\
\hline Rest between repetitions & \multicolumn{9}{|c|}{2 minutes } \\
\hline The number of sets & 8 & 8 & 8 & 8 & 8 & 8 & 8 & 7 & 7 \\
\hline Number of sessions per week & 4 & 5 & 5 & 5 & 6 & 6 & 6 & 5 & 5 \\
\hline
\end{tabular}

of the device. However, to prevent the possible effects of electric shock on the test results, in the familiarization phase with the activity on the treadmill, the animals were taught with sound conditioning to prevent approaching and resting at the end of the device. Pomegranate tablets (from Amy Vital) were prepared, and after powdering, $400 \mathrm{~g}$ of it was soaked with $2200 \mathrm{~mL}$ of $80 \%$ ethanol for 72 hours. A rotary apparatus then separated the smooth and solvent solution. The solution was stored at $-20^{\circ} \mathrm{C}$ until further use. The dose of gavage was determined to be $200 \mathrm{mg} / \mathrm{kg}$ body weight, and during the research period, the rats were fed daily by the animal technician in divided doses by gavage [13].

The rats were anesthetized with ether 48 hours after the last training session, and then $5 \mathrm{~mL}$ of blood were sampled from the rats' hearts. The blood samples were immediately poured into laboratory tubes and kept at $4^{\circ} \mathrm{C}$ for $30 \mathrm{~min}$. The serum of blood samples was then centrifuged at $200 \times \mathrm{g}$ (Pars Azmoun-Iran) for 10 minutes and kept at $-20^{\circ} \mathrm{C}$ until further steps. Serum CRP was measured by the ELISA method with the help of a kit (Biosystem-31079C3-Spain) made in Spain. Hydrogen peroxide decomposition at 240 $\mathrm{nm}$ was used to measure the CAT enzyme. To measure SOD, we used the Ransel kit (Randox, UK) according to the manufacturer's instructions. The concentration was determined by the Bradford method at $595 \mathrm{~nm}$. Enzyme activities were reported in IU/mg.

All measurements were performed by a Hitachi 912 biochemical autoanalyzer (made in Japan) with a variety of conventional biochemical methods and 12 wavelengths from 340 to $750 \mathrm{~nm}$ plus a silicon photodiode detector. The detector had "Within Run Precision" and "between Run Precision control" and, with a valid control serum, determined the device repeatability through ten times testing of a specific sample and reported the average, standard deviation, and its percentage (Mean, $\mathrm{SD}, \mathrm{CV} \%$ ).

The results were reported as the mean and standard deviation. After collecting the raw data of the experiment, the

Table 2. Results of 1-way analysis of variance test of research variables in four groups

\begin{tabular}{|c|c|c|c|c|c|}
\hline Variable & Sources of Variance & Sum of Squares & Average of Squares & $\mathbf{F}$ & $\mathbf{P}$ \\
\hline \multirow{3}{*}{ C-reactive protein } & Between groups & 14 & 46 & \multirow{3}{*}{6.8} & \multirow{3}{*}{$0.002^{*}$} \\
\hline & Intergroup & 100 & \multirow{2}{*}{4.66} & & \\
\hline & Total & 114 & & & \\
\hline \multirow{3}{*}{ Catalase } & Between groups & 16 & 44 & \multirow{3}{*}{4.4} & \multirow{3}{*}{$0.003^{*}$} \\
\hline & Intergroup & 98 & \multirow{2}{*}{10.2} & & \\
\hline & Total & 114 & & & \\
\hline \multirow{3}{*}{ Superoxide dismutase } & Intragroup & 12 & 64 & & \multirow{3}{*}{$0.000^{*}$} \\
\hline & Intergroup & 100 & \multirow{2}{*}{12.4} & 6.4 & \\
\hline & Total & 112 & & & \\
\hline
\end{tabular}




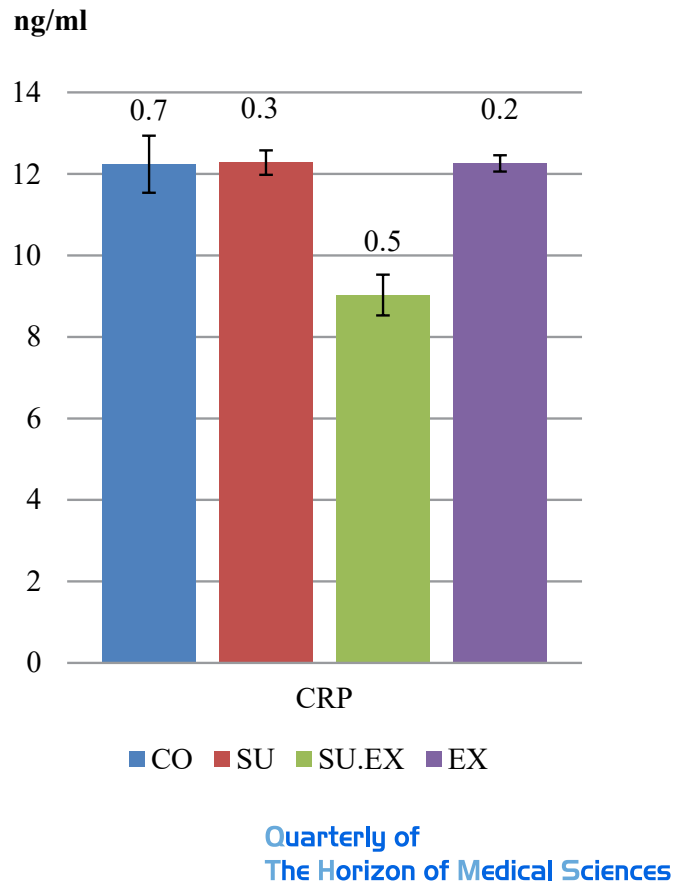

Figure 1. Comparison of mean and standard deviation changes of C-reactive protein $(\mathrm{ng} / \mathrm{mL})$ between four research groups

Shapiro-Wilk test was used to ensure the normal distribution of data, and Levene's test to check the homogeneity of variance. A 1-way Analysis of Variance (ANOVA) test was used to evaluate the differences between research variables among the experimental groups. Tukey's post hoc test

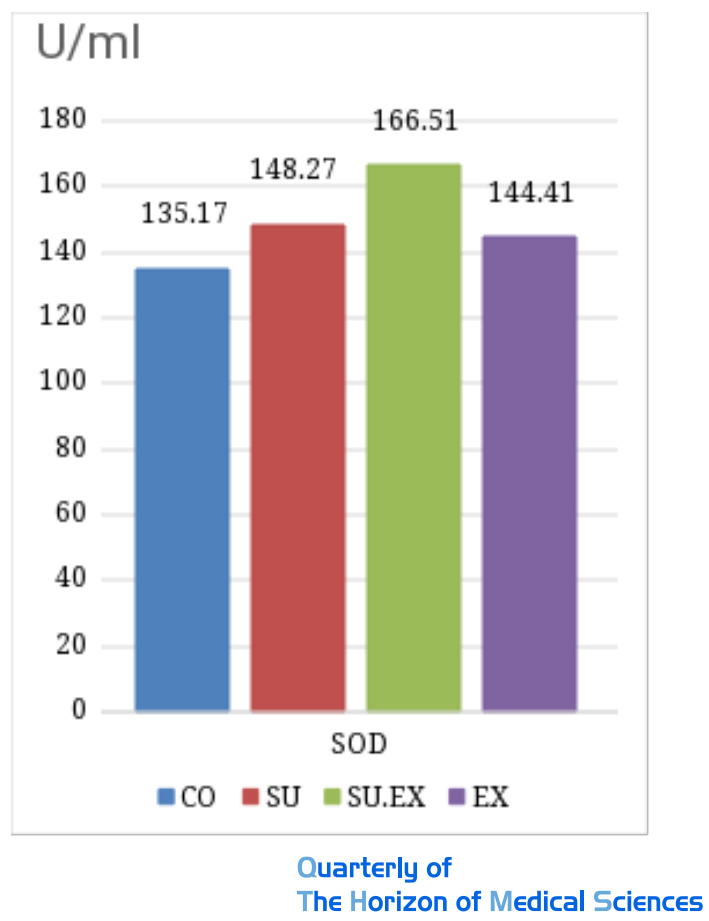

Figure 3. Comparison of mean and standard deviation changes of superoxide dismutase $(\mathrm{U} / \mathrm{mL})$ between four research groups

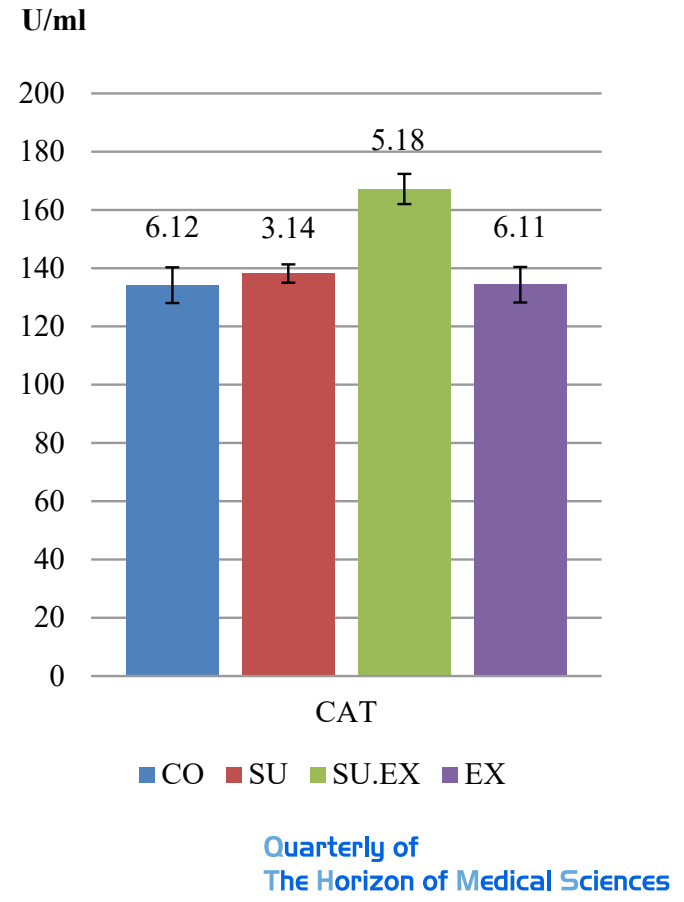

Figure 2. Comparison of mean and standard deviation changes of Catalase $(\mathrm{U} / \mathrm{mL})$ between four research groups

assessed the significance of the results. Statistical analysis was performed by SPSS version 24 .

\section{Results}

The descriptive results of the research were presented in the form of tables and graphs. Rats at the beginning of the study protocol had a Mean \pm SD weight of $260 \pm 32 \mathrm{~g}$ and a Mean \pm SD age of $72 \pm 3$ months. The results of comparing the inflammatory variable of CRP in rats are shown in Figure 1. The results of comparing the antioxidant enzyme CAT of rats can be seen in Figure 2. The results of comparing the antioxidant enzyme SOD in rats can be seen in Figure 3.

According to the results, the assumption of homogeneity of variance and data distribution in the experimental groups was normal. The results of the 1-way ANOVA test of research variables are shown in Table 2 .

Based on the results of 1-way ANOVA, the difference between the means of the CRP variable was significant only between the control group and the group of hydroethanolic extract of pomegranate peels + intense interval exercise. Tukey's test confirmed CRP results between the control group and the hydroethanolic extract group of pomegranate peel + intense interval exercise and the group that had intense interval exercise $(\mathrm{P}<0.05)$. Based on the results of 1-way ANOVA, the difference between the control group and the other three groups on the mean of SOD was sig- 
nificant. Tukey's test confirmed the significance of results for SOD between the control group and the other three groups $(\mathrm{P}<0.05)$. Based on the results of 1-way ANOVA, the difference between the control group and the other three groups on the means of CAT was significant. The Tukey's test confirmed the significance of CAT results only between the control group and the hydroethanolic extract group of pomegranate peels + intense interval exercise $(\mathrm{P}<0.05)$.

\section{Discussion}

This study showed that the amount of CRP decreased after a period of intense interval exercise and consumption of hydroethanolic extract of pomegranate peels. However, pomegranate supplement alone could not change the level of this cytokine factor. In rats with pomegranate supplement and intense intermittent exercise, the CRP plasma level decreased compared to the control group. In the study of Farhadi et al., the amount of CRP was reduced after taking pomegranate supplements and exercise [14].

It seems that the use of pomegranate pill supplement along with exercise causes homeostasis by activating antiinflammatory factors that reduce CRP, and several mechanisms do this reduction. The decrease in cytokine production resulted from the improvement of endothelial function due to exercise and the possible antioxidant effects of pomegranate supplementation [15]. Also, the compounds of pomegranate ellagic polyphenols inhibited the expression of CRP genes [16]. Like the present study results, Ammar et al. observed that pomegranate supplementation in runners significantly reduced CRP levels. They believed that the polyphenols in pomegranate reduce CRP levels by suppressing the activity of the cyclooxygenase- 2 enzyme and interference with regulating some pro-inflammatory indicators such as tumor necrosis factor [17].

Contrary to the results of the present study, Trambold et al. observed that daily consumption of $500 \mathrm{~mL}$ of pomegranate juice in the first 5 days of exercise, although not reducing pro-inflammatory factors such as CPR, over time, the alginate in pomegranate juice significantly reduced CRP in athletes [18]. Another study showed that the anti-inflammatory effect of pomegranate on the body of athletes after exercise depends on the dose and duration of its use [19]. Therefore, the lack of CRP reduction in the group that used only the hydroethanolic extract of pomegranate peels may be attributed to the low supplement dose and short test time. The synergistic effect of using the hydroethanolic extract of pomegranate peels and intermittent exercise, which is shown in reducing inflammatory protein $\mathrm{CRP}$, is due to the successful control of inflammation by this synergy.
Regarding the levels of the SOD enzyme, the results showed that after training and supplementation, this enzyme level increased significantly in all experimental groups. Consumption of hydroethanolic extract of pomegranate peels and intense interval training increased the levels of this antioxidant enzyme. In the case of CAT, a significant increase in the plasma level of the enzyme was reported only in the group that used the hydroethanolic extract of pomegranate peels simultaneously with intermittent exercise. Moder et al. also reported that short- and medium-term increasingly intense aerobic exercise without supplementation did not significantly alter SOD and CAT levels in rats [20].

The disproportionate balance between changes in these enzymes has also been reported after exercise [21]. This imbalance between the serum levels of these two enzymes can be attributed to the effect of pro-inflammatory factors, which can be seen in the increased expression of SOD mRNA molecules [22]. Some studies have also shown an increase in serum SOD levels and no increase in serum CAT levels in trained rats. Some researchers believe that high-intensity, prolonged physical activity is associated with an increase in free radicals. Excessive oxygen supply to tissues is one of the most important causes of increased oxidative stress, and this increase is the result of intense aerobic exercise [23]. In this regard, Trambold et al. showed that consumption of pomegranate extract increases antioxidant levels [24].

One of the main constituents of pomegranate fruit is phenolic compounds which, due to their hydroxyl groups, can directly neutralize free radicals and enhance the function and synthesis of endogenous antioxidant enzymes in the body [25]. Similar results were observed in dogs after taking pomegranate pills and a period of exercise $[26,27]$. In this regard, it has been reported that the use of pomegranate supplementation has increased the levels of SOD in young male athletes [28]. The ingredients of pomegranate tablets are essential because of their biological role in health and strengthening the immune system [29]. Also, several elements and organic acids, and abundant alkaloids have directly or indirectly strengthened the immune system and affected research variables [30].

\section{Conclusion}

The present study results showed that a period of intense intermittent exercise with hydroethanolic extract of pomegranate peels reduced C-reactive protein (one of the proteins of the acute phase of inflammation). The novelty of the research is that taking pomegranate pill supplements and intense intermittent exercise with similar benefits will synergistically 
reduce inflammation. Therefore, adding pomegranate pills to athletes' diet can help their health, better quality of sports, and physical performance, without side effects.

\section{Ethical Considerations}

\section{Compliance with ethical guidelines}

This study was approved by the Ethics Committee of the Medical Sciences of Islamic Azad University, Varamin Pishva Branch(Code: IR.IAU.VARAMIN.REC.1398.011).

Funding

This study was extracted from MA. thesis of the second author at the Department of Sports Physiology, Varamin Pishva Branch, Islamic Azad University, Varamin.

\section{Authors' contributions}

Conceptualization, methodology, investigation, funding acquisition, resources: All author; Writing - original draft, writing - review \& editing, supervision: Farah Nameni.

\section{Conflicts of interest}

The authors declared no conflict of interest.

\section{Acknowledgements}

We appreciate all the staff, officials, and technicians of the laboratory Islamic Azad University, Varamin-Pishva Branch who helped us in this research. 
This Page Intentionally Left Blank 


\title{
كأثير مصرف عصاره هيدرواتانولى يوست ميوه انار و تمرين ثناوبى شديد بر يروتئين واكنشى C،
}

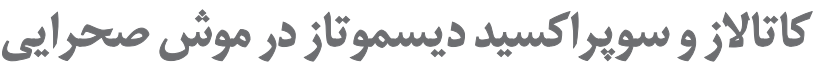

"فرح نامنى' ـ. رؤيا علىاكبر علوى'

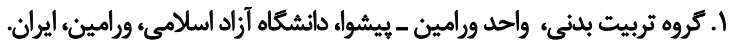

\begin{abstract}
as

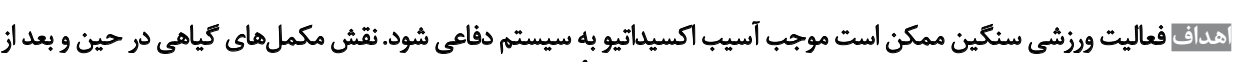

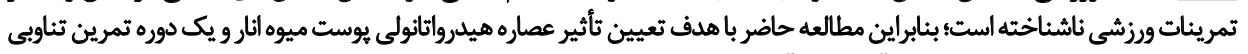

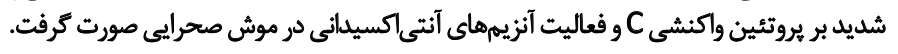

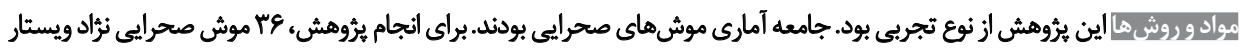

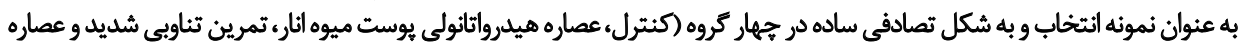

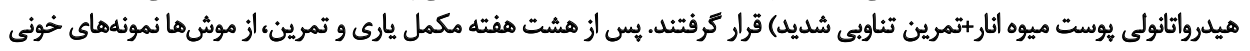

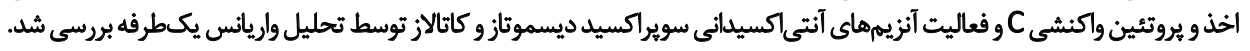

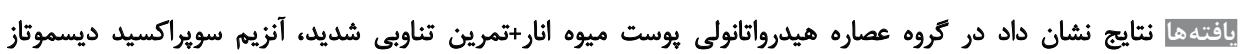

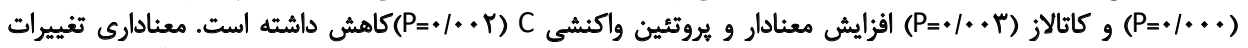

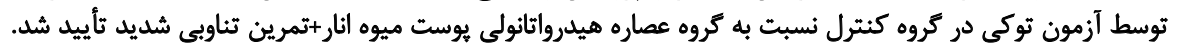

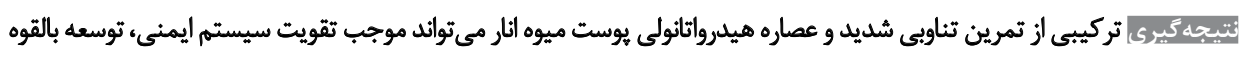

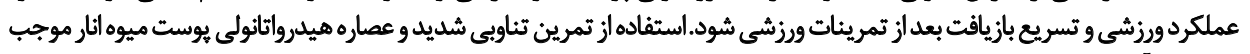

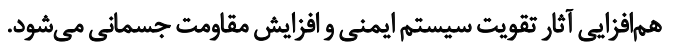

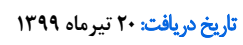

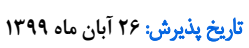

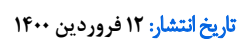

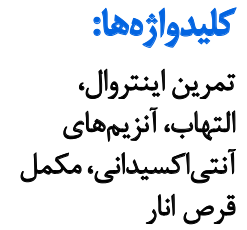

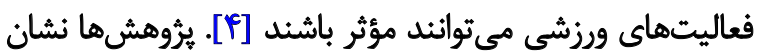

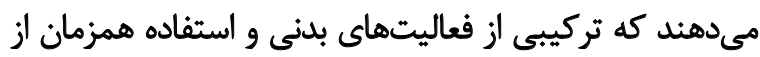

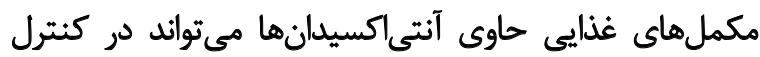
سايتوكاينهاى التهابى نقش داشته باشي باشد [ه]. استفاده از طب كياهى به عنوان نوعى روش درماني و تكميلى،

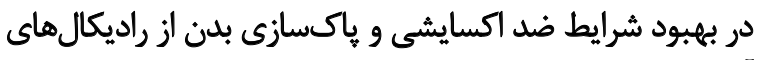

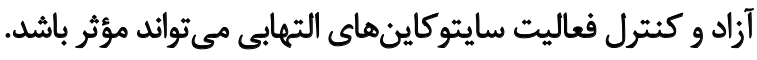

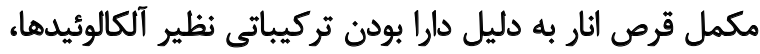

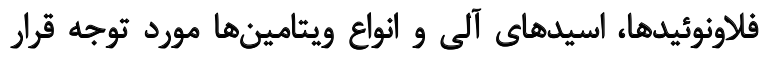

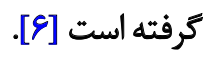

انار به دليل داشتن تركيبات منحصر به فرد بإلىفنولى باليا

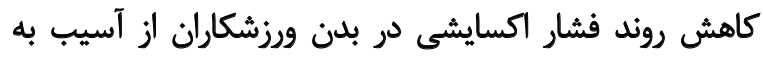

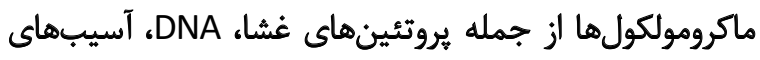

dalö

تمرينات ورزشى شديد با مصرف اكسيرن زياد موجب توليد

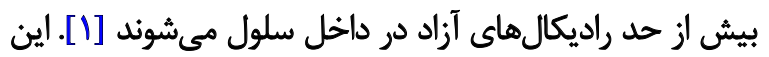

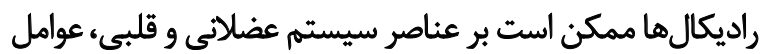

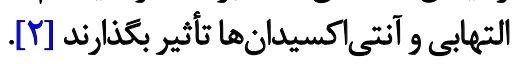

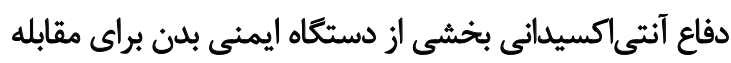

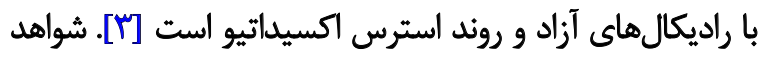

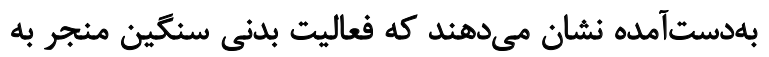

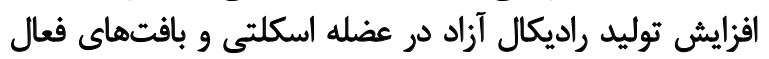

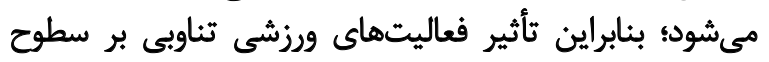

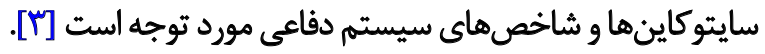
به روشنى مشخص نيست كه جه شدتى و جه زمانى از اين

$$
\text { دكتر فرح نامنى مسثول: }
$$

نشانى: ورامين، دانشكاه آزاد اسلامى، واحد ورامين - ييشوا، كروه تربيت بندى.

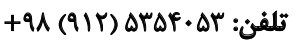
f.nameni@yahoo.co.uk: بلكن الكترونيكي 


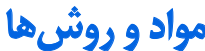

اين تحقيق به روش تجربى يا آزمايشعَاهى مداخلهكر با طرح

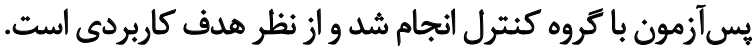

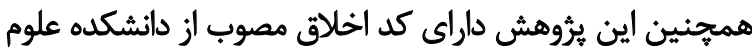

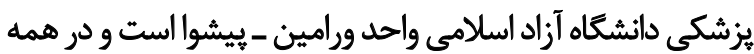

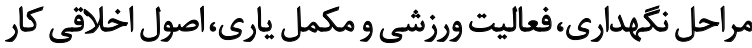

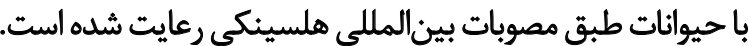
جامعه آمارى تحقيق شامل موشهاى صحرايى نر نرّاد ويستار

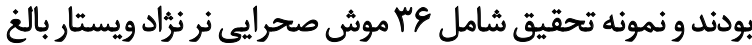

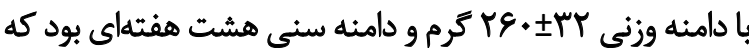

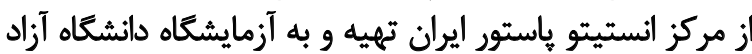

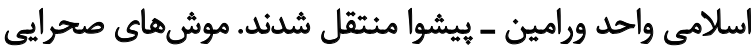
در دما و شرايط زيستى مناسب قرار ترفتند.

در هر قفس جهار موش با رعايت جرخه نورى طبيعى (دوازده

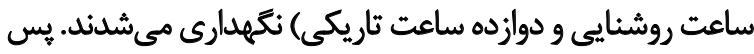

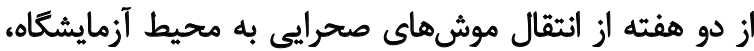

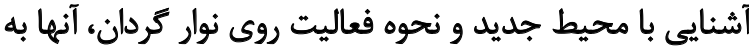

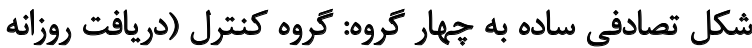

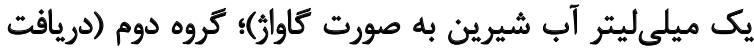

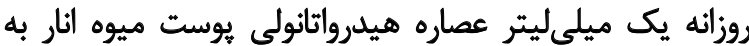

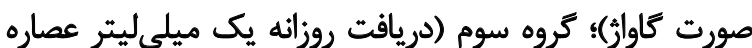

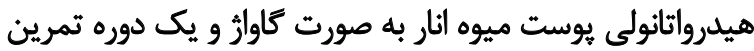

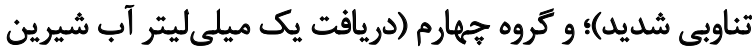

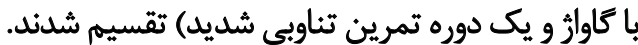

بنابراين معيارهاى ورود شامل وزن، سن، جنس، عدم استفاده از

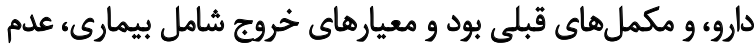

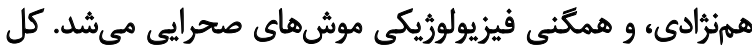

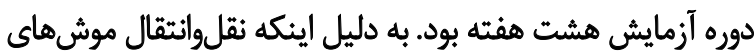

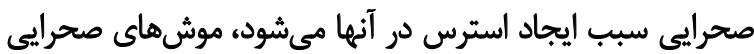

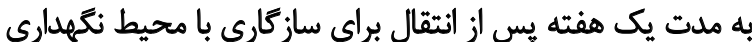

يُّنئ.

سيس براي آشنايى با تردميل به مدت يك هفته نيز تمرينات

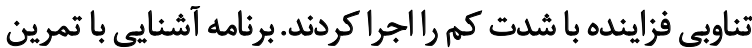

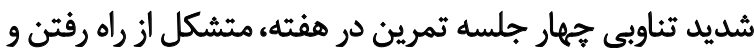

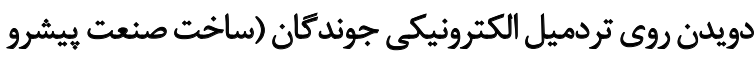
انديشه صنعت ايران) بود (جدول شماره ()).

در ينج هفته اول تمرين فزاينده و در دو هفته آخر كاهش

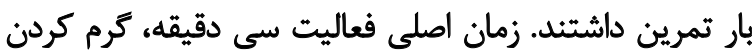

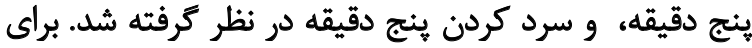

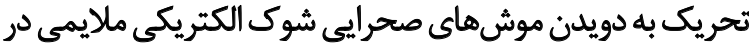

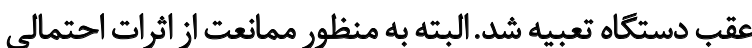

التهابى و عضلانى محافظت مى كند. به علاوه، مكمل قرص أنار

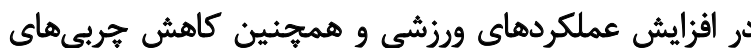

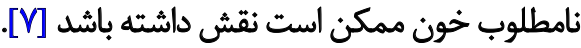
برخى اثرات ديكر يزشكى و بالينى ثركيبات زيست فعال موجود

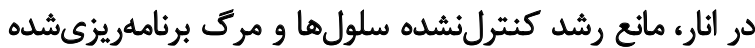

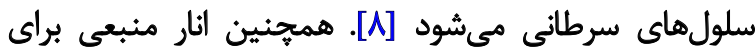

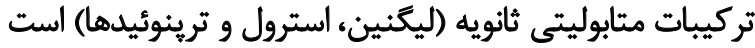

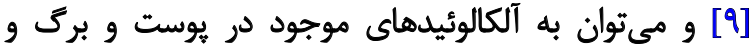

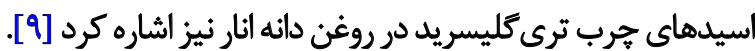
تركيبات كومارين، تانن، فلاونوئيد، آنتوسيانينها، مشتقات

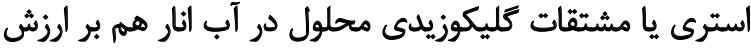

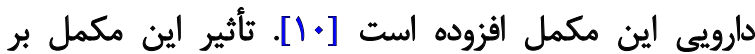

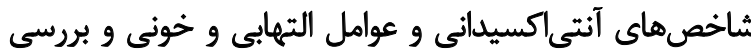

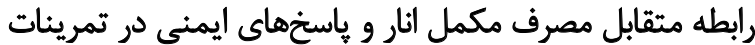

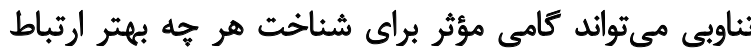

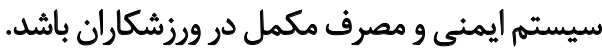
سايتو كاينهاي داراى خواص ضدالتهابي و تنظيم كنئده سيستم

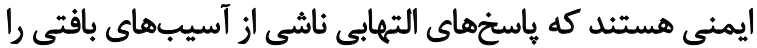

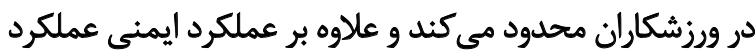

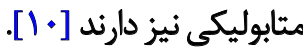
يك ميانجى اصلى واكنشهاى التهابي كه در آسيبديدكى هاي

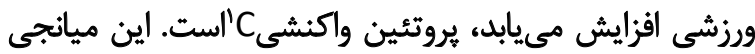

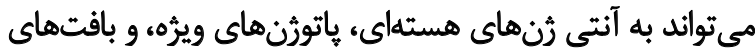

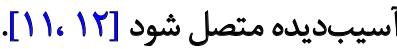

تأثير مكمل قرص انار بر سايتوكاينهاي ايمنى و هميجنين

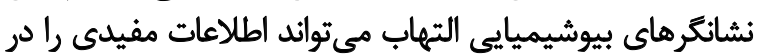

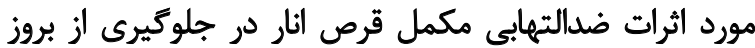

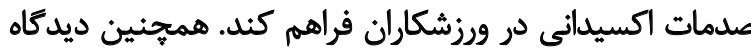

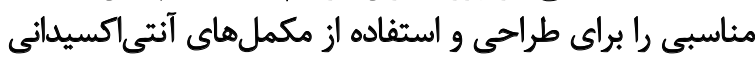
و اثرات محافظتى آنها هنكام انجام تمرينات تناوبى فراهم كند. همجنين استفاده از مكمل قرص انار در بهببود كارايى

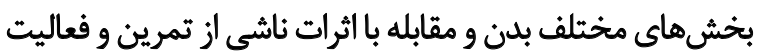

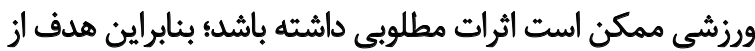

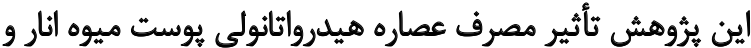

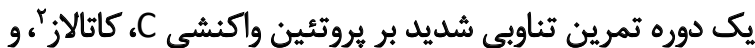

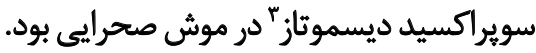

1. C-Reactive Protein

2. Catalase

3. Superoxide dismutase 


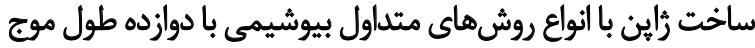

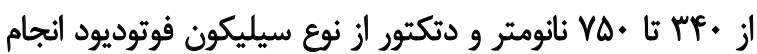

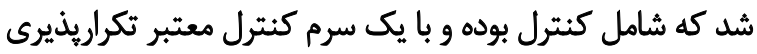

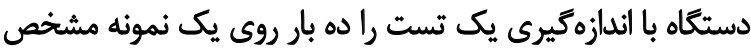
اجرا، ميانكين، انحراف معيار و درصد آن را را (Mean, SD, CV/.

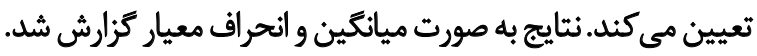

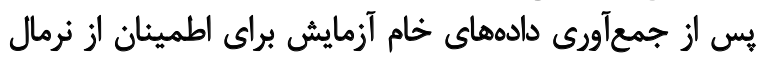

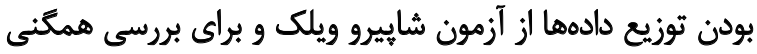

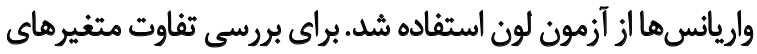

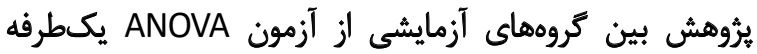

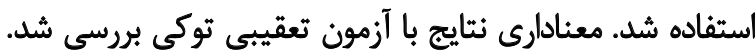

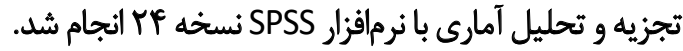

ياقثنها

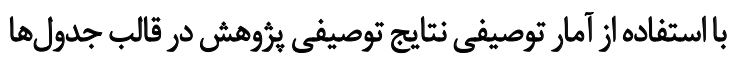

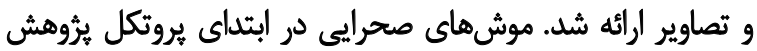

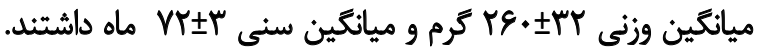

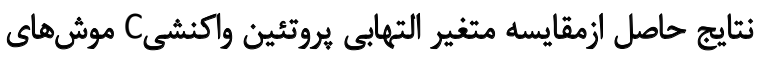
صحرايى در تصوير شماره ا مشاهده مى إنود.

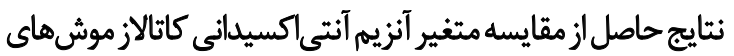

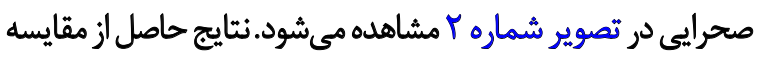

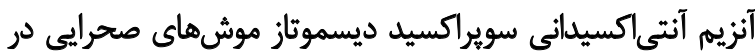
تصوير شماره ب مشاهده مىشود.

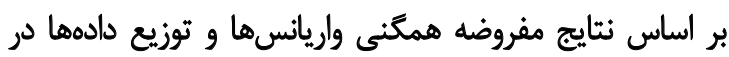

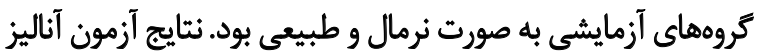

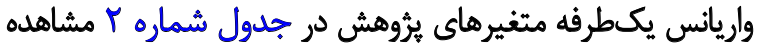

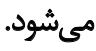

بر اساس نتايج تجزيهوتحليل واريانس يكسطرفه تفاوت ميانكينهاي

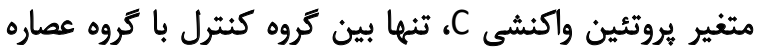
هيدرواثاثولى يوست ميوه انار +تمرين تناوبي شدين شديد معنادار بوده است. آزمون توكى معنادارى نتايج رادر مورد يروتئين واكنشى Cبين
شوك الكتريكى بر نتايج آزمايش، در مرحله آشناسازى با فعاليت

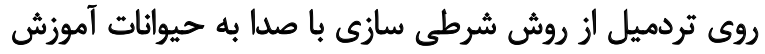

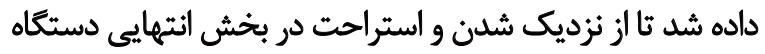

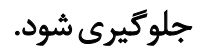

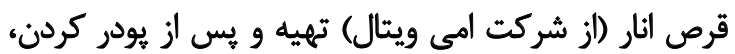

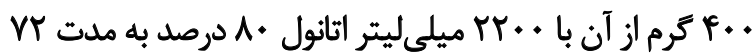

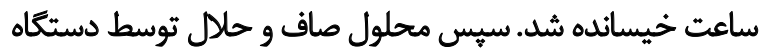

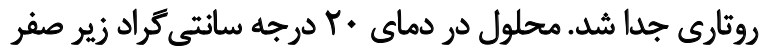

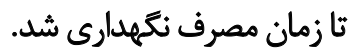

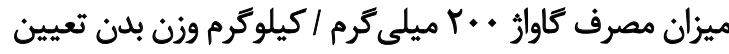

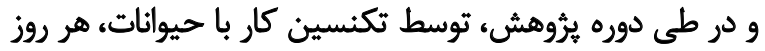

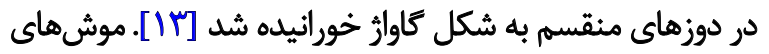

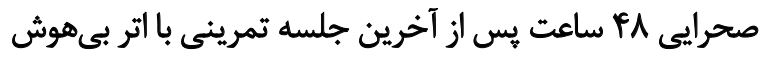

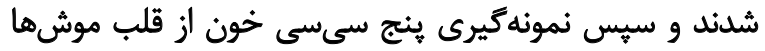

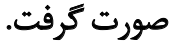

نمونهاي خون بلاقاصله به داخل لوله دائ آزمايشكاهي ريخته

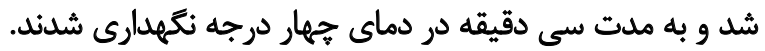

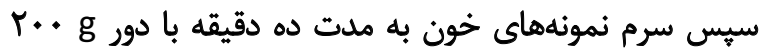

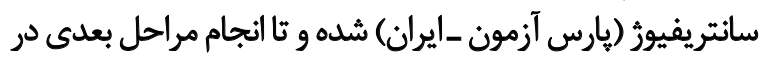
دماى • r- درجه سانتى كراد نكتهدارى شدند.

سنجش سطح سرمى CRP نيز به كمك روش ELISA و با كمى كيت (Biosystem-31079C3-Spain) ساحُت كشور

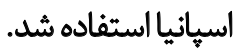
براى سنجش آتزيم كاتالاز از روش تجزيه يراكسيد هيدروثن يران

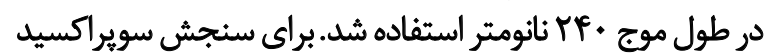

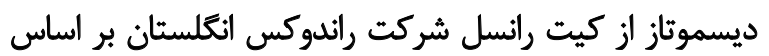

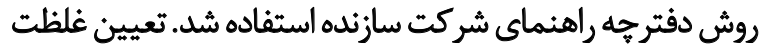

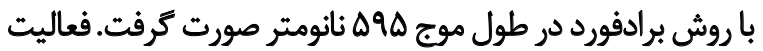

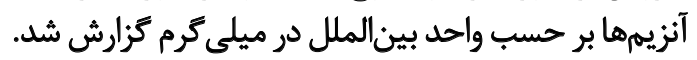

همه سنجشها با دستكاه اتوآنالايزر بيوشيمى هيتاجى

جدول ا. برئامه تمريني هشت هفتهاي ايتتروال آزمودنىها

\begin{tabular}{|c|c|c|c|c|c|c|c|c|c|}
\hline هشتم & هفتم & ششم & ينجم & جهارم & سوم & 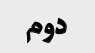 & اول & آشنايى & هفته \\
\hline$\varepsilon_{+}-\gamma \cdot$ & $\varepsilon+-\gamma$. & $\Delta+-8 \Delta$ & $P \Delta-\Delta \Delta$ & $r \cdot-F \Delta$ & ra-Ta & $r \Delta-r \Delta$ & ra-ra & $1 .-r \Delta$ & " سرعت تمرين \\
\hline & & & & يك دقيقه & & & & & ملت تمرين \\
\hline & & & & دو دقيقه & & & & & أستراحت بين ثكرار \\
\hline$\checkmark$ & $\checkmark$ & $\wedge$ & $\wedge$ & $\wedge$ & $\Lambda$ & $\wedge$ & $\Lambda$ & A & تعلاد ست \\
\hline$\Delta$ & $\Delta$ & 8 & 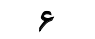 & $q$ & $\Delta$ & $\Delta$ & $\Delta$ & $f$ & تعلفاد جلسيه در هُتَه \\
\hline
\end{tabular}


جدول r. نتايج تجزيهوتحليل واريانس يكىطرفه متغيرهاي ثيروهش در جهار تروه

\begin{tabular}{|c|c|c|c|c|c|}
\hline p* & $\mathbf{F}$ & ميانكين مربعات & مجموع مربعات & منابع واريانس & مثغير \\
\hline \multirow{3}{*}{$+1+\cdot r$} & \multirow{3}{*}{$8 / \lambda$} & $p q$ & if & بين كروهى & \multirow{3}{*}{ CPR } \\
\hline & & \multirow{2}{*}{ P/g9 } & $1 .$. & درون كروهى & \\
\hline & & & $11 f$ & كل & \\
\hline \multirow{3}{*}{ r... } & \multirow{3}{*}{$\varphi / \varphi$} & pr & 18 & بين كروهى & \multirow{3}{*}{ CAT } \\
\hline & & \multirow{2}{*}{$r / l}$. & $u$ & درون كروهى & \\
\hline & & & lif & كل & \\
\hline \multirow{3}{*}{.$\ldots$} & \multirow{3}{*}{$8 / f^{\circ}$} & sp & ir & يين كروهى & \multirow{3}{*}{ SOL } \\
\hline & & \multirow{2}{*}{$r / N r$} & $1 .$. & درونكروهى & \\
\hline & & & IIT & كل & \\
\hline
\end{tabular}

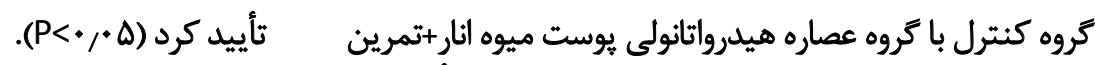

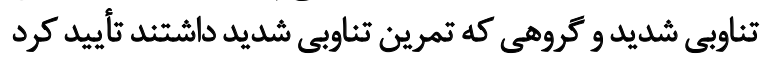
. $(P<\bullet, \bullet \bullet)$

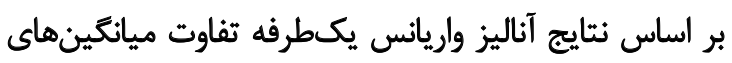

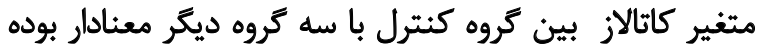

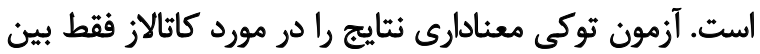

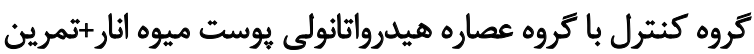

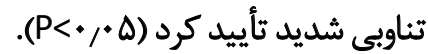

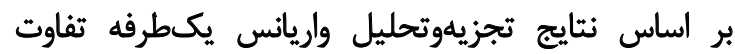

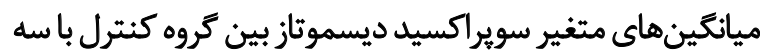

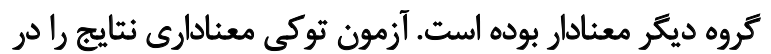

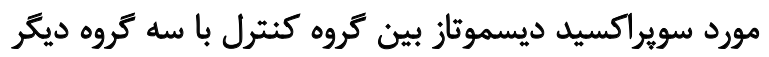

$\mathbf{U} / \mathbf{m l}$

$\mathbf{n g} / \mathbf{m l}$

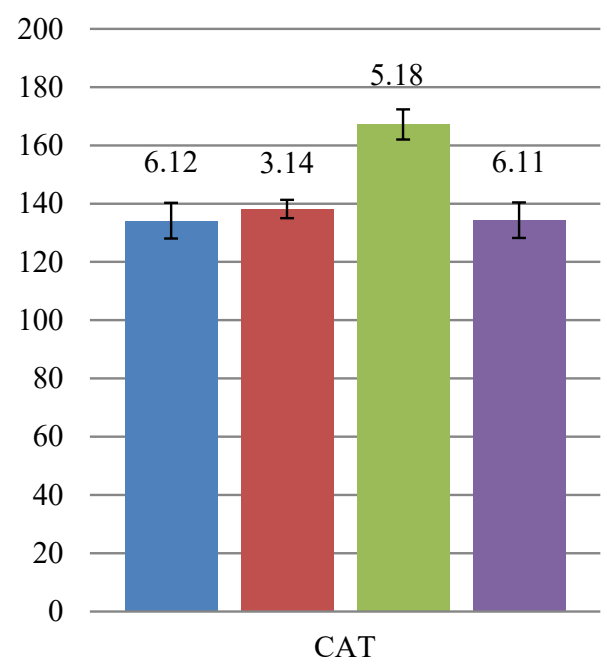

$\square \mathrm{CO} \backsim \mathrm{SU} \backsim \mathrm{SU} . \mathrm{EX} \backsim \mathrm{EX}$

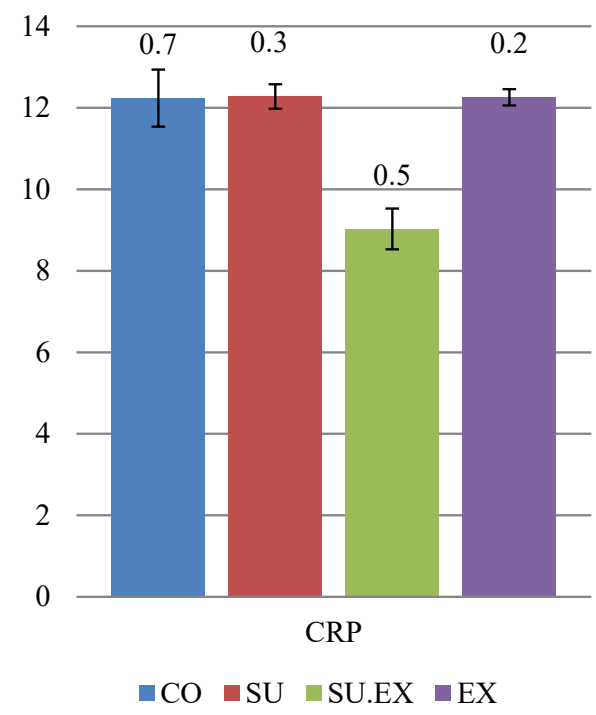

\section{انقّراتُ}

تصوير T. مقايسه تغييرات ميانكين و انحراف معيار CAT (واحد بر ميلىليتر)

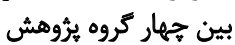

أقُ وانث

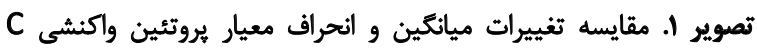

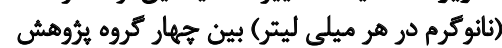


كاهش سطوح CPR شده است [IV]. برخلاف نتايج مطالعه حاضر، ترامبولده و همكارانش مشاهده

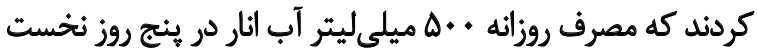

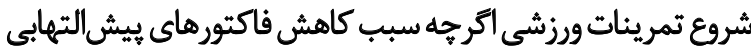

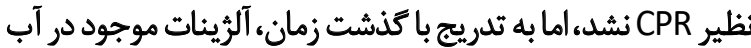

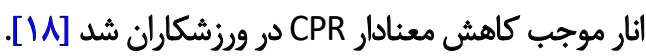
تحقيق ديكرى نشان داده بود كه اثر ضدالتهابى انار بر بدن

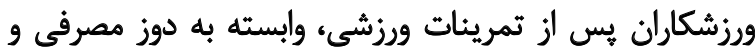

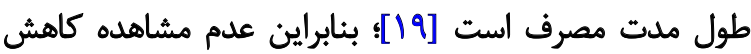

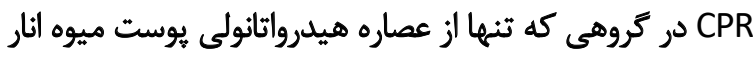

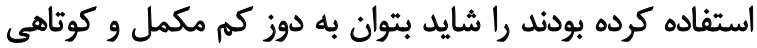

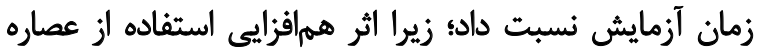

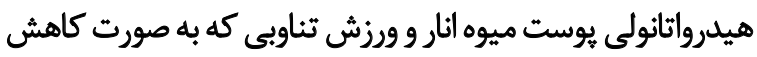

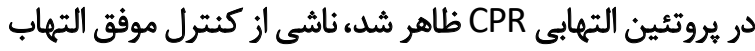

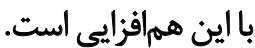

در رابطه با سطوح آنزيم سويراكسيد ديسموتاز، نتايج نشان داد

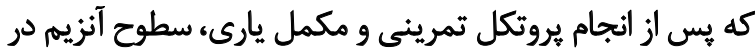
همه كروههاى آزمايشى افزايش معناداري داشت ندئ.

در واقع مصرف عصاره هيدرواتانولى يوست ميوه انار و و

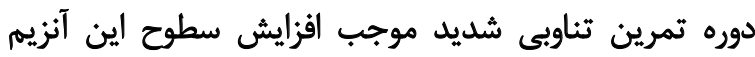

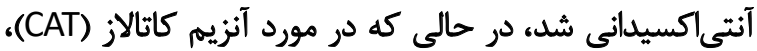

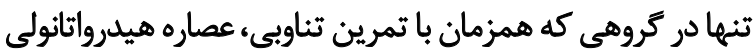

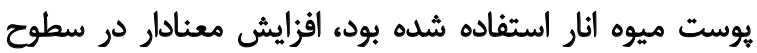

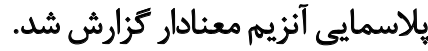

مدير و همكاران نيز كزارش كردند كه تمرينات هوازي شديد

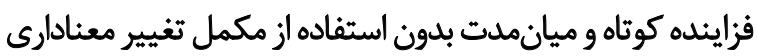

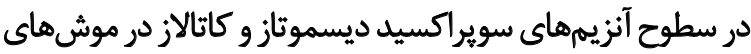

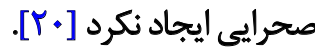

عدم تناسب و تعادل بين تغييرات اين آنزيمها يُ إس از تمرينات

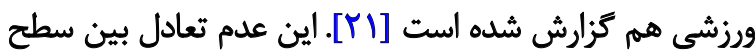

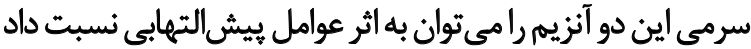

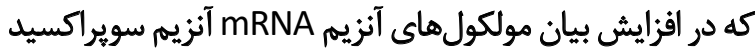

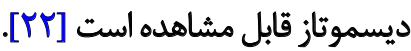

در برخى از تحقيقات نيز افزايش سطح سرمى سويراكسيد

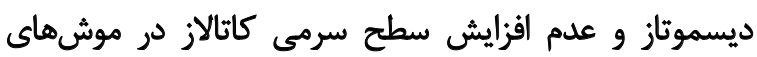

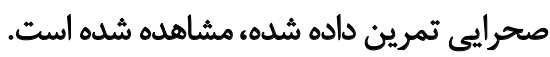

برخى از محققان معتقدند كه فعاليتهاي بدنى با شدات بالا بالاو

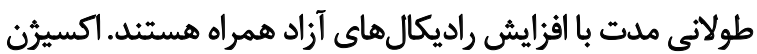

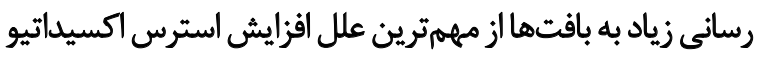

$\mathbf{U} / \mathbf{m l}$

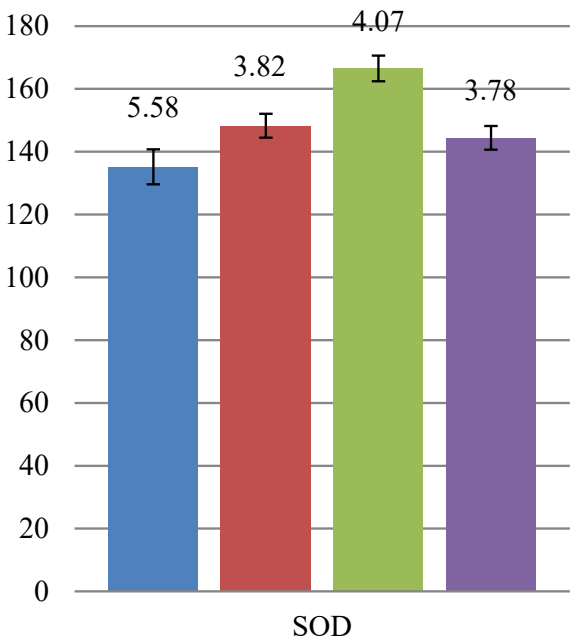

$\square \mathrm{CO} \backsim \mathrm{SU} \backsim$ SU.EX $\square$ EX

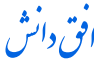

تصوير ب. مقايسه تغييرات ميانكين و انحراف معيار SOD (واحد بر ميلىليتر)

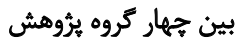

\section{to}

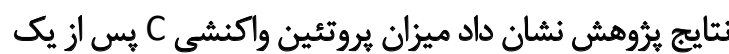

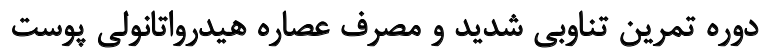

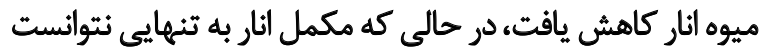

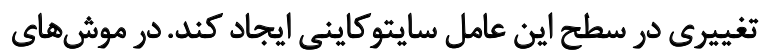

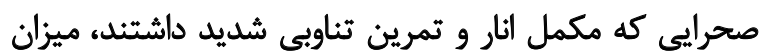

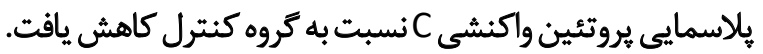

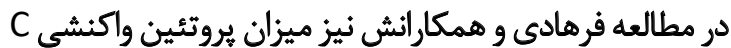

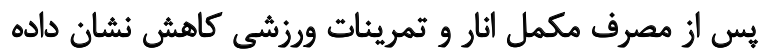

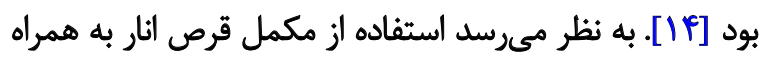

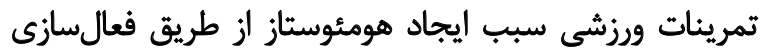
عوامل ضدالتهابي شده كه موجب كاهش كاهش به كمك جندين سازوكار صورت مي مئه مايرد. كاهش توليد سايتوكاينها حاصل بهبود عملكرد اندوتليالى در ائري

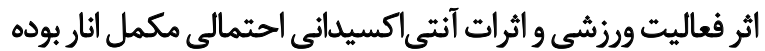

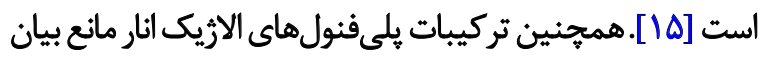
كُنهاى CPR شده است [19]. مطابق نتايج يثوهش حاضر، در مطالعه امارّ و همكارانش

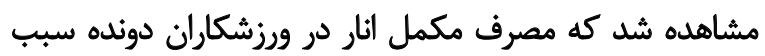

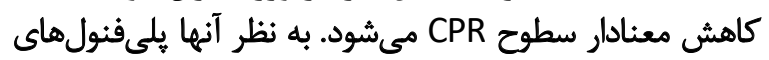

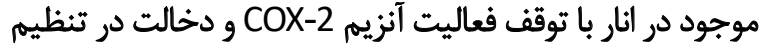
برخى شاخص هاي بيش التهابي نظير فاكتور نكروز تومورى سبت فيب 


\section{تمعارض مئاقع}

بنابر اظهار نويسندكان اين مقاله تعارض منافع ندارد.

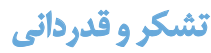

نويسند كان از مسئولين و تكنسينهاى آزمايشعاه دانشكاه آزاد اسلامى واحد ورامين - يُيشوا تشكر مى كنند.
است و اين افزايش حاصل تمرينات ورزشى هوازى شديد است

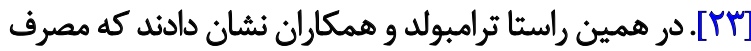

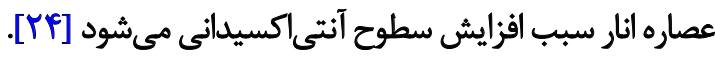

از تركيبات اصلى ميوه انار تركيبات فنوليك است كه به دليل

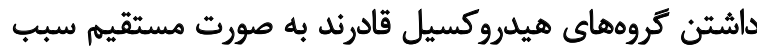

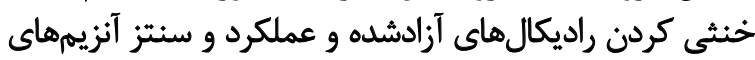

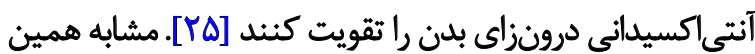

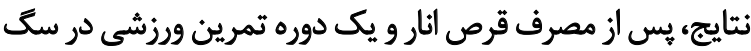

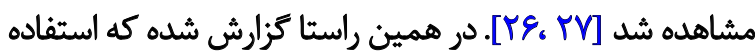

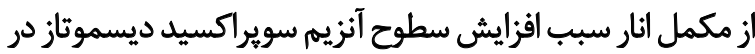

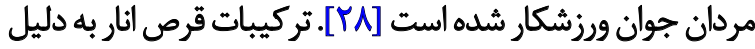

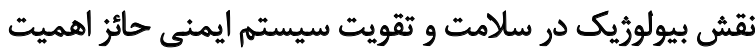

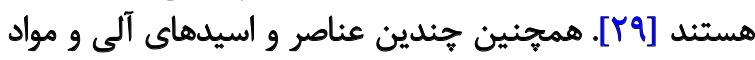

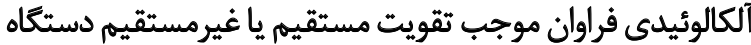

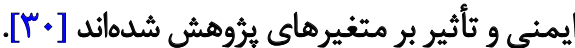

$$
\text { تئيجليرى }
$$

نتايج يرؤش حاضر نشان داد كه يك دوره تمرين تناوبى

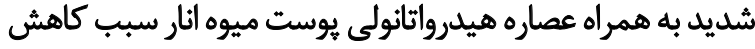

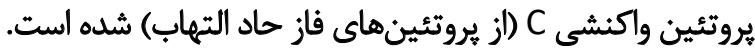

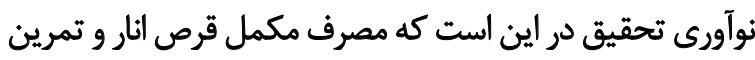

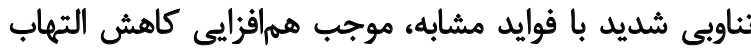

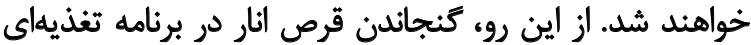

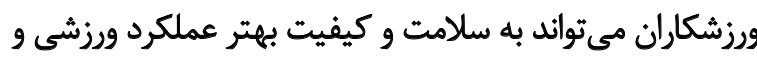
جسمى آنها، بدون عوارض باند بانبى كمك شايانى كند.

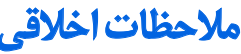

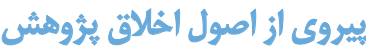

اين ثرّوهش مورد ثاييد كميته اخلاق دانشكده علوم يزشكى

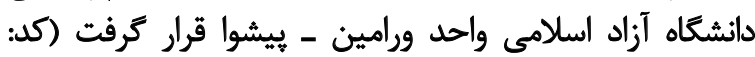
.(IR.IAU.VARAMIN.REC.1398.011

$$
\text { مامي مالى }
$$

اين مقاله مستخرج از بايان نامه كارشتاسى ارشد خانم رويا

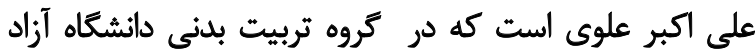
اسلامى، واحد ورامين-بيشوا بدون حمايت دروه مايت مالى تنظيمى و اجرا

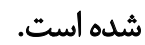

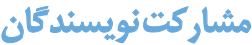

مفهوم سازى، روششناسى، اعتبار سنجى، تحليل، تحقيق و و

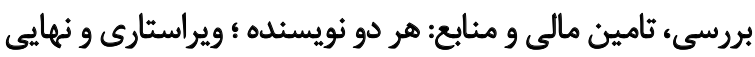

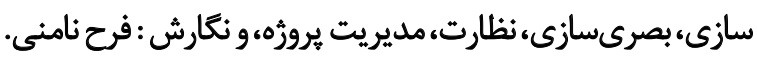




\section{References}

[1] Halliwell B, Gutteridge JM. Free radicals in biology and medicine. $5^{\text {th }}$ ed. United Kingdom: Oxford University Press; 2015. [DOI:10.1093/acprof:o so/9780198717478.001.0001]

[2] MacRae HSH, Mefferd KM. Dietary antioxidant supplementation combined with quercetin improves cycling time trial performance. International Journal of Sport Nutrition and Exercise Metabolism. 2006; 16(4):405-19. [DOI:10.1123/ijsnem.16.4.405] [PMID]

[3] Beavers KM, Brinkley TE, Nicklas BJ. Effect of exercise training on chronic inflammation. Clinica Chimica Acta. 2010; 411(11-12):785-93. [DOI:10.1016/j.cca.2010.02.069] [PMID] [PMCID]

[4] Basu A, Penugonda K. Pomegranate juice: A heart-healthy fruit juice. Nutrition Reviews. 2009; 67(1):49-56. [DOI:10.1111/j.17534887.2008.00133.x] [PMID]

[5] Davison G,Gleeson M. Influence of acute vitamin C and/or carbohydrate ingestion on hormonal, cytokine, and immune responses to prolonged exercise. International Journal of Sport Nutrition and Exercise Metabolism. 2005; 15(5):465-79. [DOI:10.1123/ijsnem.15.5.465] [PMID]

[6] Aviram M, Dornfeld L, Rosenblat M, Volkova N, Kaplan M, Coleman R, et al. Pomegranate juice consumption reduces oxidative stress, atherogenic modifications to LDL, and platelet aggregation: Studies in humans and in atherosclerotic apolipoprotein E-deficient mice. The American Journal of Clinical Nutrition. 2000; 71(5):1062-76. [DOI:10.1093/ ajcn/71.5.1062] [PMID]

[7] Akhtar S, Ismail T, Layla A. Pomegranate bioactive molecules and health benefits. In: Mérillon JM, Ramawat $\mathrm{K}$, editors. Bioactive molecules in Food. Reference series in phytochemistry. Switzerland: Springer, Cham; 2019. [DOI:10.1007/978-3-319-78030-6_78]

[8] Mphahlele RR, Fawole OA, Stander MA, Opara UL. Preharvest and postharvest factors influencing bioactive compounds in pomegranate (Punica granatum L.)-A review. Scientia Horticulturae. 2014; 178:114-23. [DOI:10.1016/j.scienta.2014.08.010]

[9] Viswanath M, Sridevi P, Venkataramudu K, Naik SR, Kumar KR. Pomegranate (Punica granatum L.) processing, value addition and their Medicinal Properties related to human Health: A review. International Journal of Current Microbiology and Applied Sciences. 2019; 8(1):1722-30. [DOI:10.20546/ijcmas.2019.801.183]

[10] Carol A, Witkamp RF, Wichers HJ, Mensink M. Bovine colostrum supplementation's lack of effect on immune variables during short-term intense exercise in well-trained athletes. International journal of Sport Nutrition and Exercise Metabolism. 2011; 21(2):135-45. [DOI:10.1123/ ijsnem.21.2.135] [PMID]

[11] Kasapis C,Thompson PD. The effects of physical activity on serum C-reactive protein and inflammatory markers: A systematic review. Journal of the American College of Cardiology. 2005; 45(10):1563-9. [DOI:10.1016/j.jacc.2004.12.077] [PMID]

[12] De Almeida AA, da Silva SG, Fernandes J, Peixinho-Pena LF, Scorza FA, Cavalheiro EA, et al. Differential effects of exercise intensities in hippocampal BDNF, inflammatory cytokines and cell proliferation in rats during the postnatal brain development. Neuroscience Letters. 2013; 553:1-6. [DOI:10.1016/j.neulet.2013.08.015] [PMID]

[13] Nazari M, Sadeghipour A, Eidi M. [Effect of hydroethanolic extract of aflatoxin-induced liver injury on anarbus fruit in adult male rats (Persian)]. Developmental Biology . 1395; 8(4):23-32. https://www.sid.ir/fa/ journal/ViewPaper.aspx?id=347392

[14] Farhadi H, Rahimi F, Baqaei S. [The effect of eight weeks of pomegranate supplementation on inflammatory markers and muscle injury in non-athlete overweight men under different $\mathrm{VO}_{2}$ max intensities (Persian)]. Applied Biosciences in Sport. 1396; 5(9):31-41. https://www.sid. ir/fa/journal/ViewPaper.aspx?id=306422

[15] Dong S, Tong X, Liu H, Gao Q. Protective effects of pomegranate polyphenols on cardiac function in rats with myocardial ischemia/reperfusion injury Nan fang yi ke da xue xue bao. Journal of Southern Medical University. 2012; 32(7):924-7. [PMID]

[16] Sun YL, Zhou FM, Wang HR. Mechanism of pomegranate ellagic polyphenols reducing insulin resistance on gestational diabetes mellitus rats. American Journal of Translational Research. 2019; 11(9):5487-500. [PMCID]

[17] Ammar A, Turki M, Chtourou H, Hammouda O, Trabelsi K, Kallel C, et al. Pomegranate supplementation accelerates recovery of muscle damage and soreness and inflammatory markers after a weightlifting training session. PLOS one. 2016; 11(10):e0160305. [DOI:10.1371/journal. pone.0160305] [PMID] [PMCID]

[18] Trombold JR, Barnes JN, Critchley L, Coyle EF. Ellagitannin consumption improves strength recovery 2-3 d after eccentric exercise. Medicine and Science in Sports and Exercise. 2010; 42(3):493-8. [DOI:10.1249/ MSS.0b013e3181b64edd] [PMID]

[19] Machin DR, Christmas KM, Chou TH, Hill SC, Van Pelt DW, Trombold $\mathrm{JR}$, et al. Effects of differing dosages of pomegranate juice supplementation after eccentric exercise. Physiology Journal. 2014:271959 [DOI:10.1155/2014/271959]

[20] Moder M, Drianoush F, Firouzmand H, Jafari H, Khanzadeh M. [The effect of increasing and medium term exercise on serum levels of superoxide dismutase and catalase in rats (Persian)]. Journal of Gorgan University of Medical Sciences.1395; 16(3):24-30. http://goums.ac.ir/ journal/article-1-2113-fa.html

[21] Burneiko RC, Diniz YS, Galhardi CM, Rodrigues HG, Ebaid GMX, Faine $\mathrm{LE}$, et al. Interaction of hypercaloric diet and physical exercise on lipid profile, oxidative stress and antioxidant defenses. Food and Chemical Toxicology. 2006; 44(7):1167-72. [DOI:10.1016/j.fct.2006.01.004] [PMID]

[22] Zelko IN, Mariani TJ, Folz RJ. Superoxide dismutase multi gene family: A comparison of the CuZn-SOD(SOD1), Mn-SOD(SOD2)and EC-SOD(SOD3) gene structures, evolution and expression. Free Radical Biology and Medicine. 2002; 33(3):337-49. [DOI:10.1016/S0891-5849(02)00905-X]

[23] Yavari A, Javadi M, Mirmiran P, Bahadoran Z. Exercise-induced oxidative stress and dietary antioxidants. Asian Journal of Sports Medicine. 2015; 6(1):e24898 [DOI:10.5812/asjsm.24898] [PMID] [PMCID]

[24] Trombold JR, Reinfeld AS, Casler JR, Coyle EF. The effect of pomegranate juice supplementation on strength and soreness after eccentric exercise. The Journal of Strength \& Conditioning Research. 2011; 25(7):1782-8. [DOI:10.1519/JSC.0b013e318220d992] [PMID]

[25] Ghavipour M, Sotoudeh G, Tavakoli E, Mowla K, Hasanzadeh J, Mazloom Z. Pomegranate extract alleviates disease activity and some blood biomarkers of inflammation and oxidative stress in Rheumatoid Arthritis patients. European Journal of Clinical Nutrition. 2017; 71(1):92-6 [DOI:10.1038/ejcn.2016.151] [PMID]

[26] Newman ED. Effects of pomegranate polyphenol supplementation on biomarkers of oxidative stress and inflammation in adults with type 2 diabetes versus healthy controls [MSc. Thesis]. United States: Oklahoma State University; 2010. https://shareok.org/handle/11244/9253

[27] Jose T, Pattanaik AK, Jadhav SE, Dutta N, Sharma S. Nutrient digestibility, hindgut metabolites and antioxidant status of dogs supplemented with pomegranate peel extract. Journal of Nutritional Science. 2017; 6:e36. [DOI:10.1017/jns.2017.34] [PMID] [PMCID] 
[28] Shaygannia E, Bahmani M, Zamanzad B, Rafieian-Kopaei M. A review study on Punica granatum $L$. Journal of Evidence-Based Complementary \& Alternative Medicine. 2016; 21(3):221-7. https://journals.sagepub. com/doi/full/10.1177/2156587215598039

[29] Kushwaha SC. Study on extraction of pomegranate ellagitannin storage stability and its application [PhD. dissertation]. India: Sant Longowal Institute of Engineering and Technology; 2016._https://shodhganga.inflibnet.ac.in/handle/10603/75331

[30] Sood A, Gupta M. Extraction process optimization for bioactive compounds in pomegranate peel. Food Bioscience. 2015; 12:100-6. [DOI:10.1016/j.fbio.2015.09.004] 
This Page Intentionally Left Blank 